\title{
Analisis Strategi Pengembangan Usaha Supermarket XYZ dengan Pendekatan Model Bisnis Kanvas
}

\author{
Analysis of Business Development Strategy of XYZ Supermarket \\ with Business Model Canvas Approach
}

\author{
Jack Absalom Soselisa ${ }^{{ }^{*}}$, Sapta Raharja ${ }^{2 \#,}$, dan Budi Suharjo ${ }^{3 \#}$ \\ ${ }^{1}$ Kem Chicks Supermarket \\ Jl. Jenderal Sudirman Kav 52-53, Jakarta Pusat \\ Telp.021-51400440, Fax. 021-51400550
}

${ }^{2}$ Departemen Teknologi Industri Pertanian, Fakultas Teknologi Pertanian IPB

${ }^{3}$ Departemen Matematika, Fakultas Matematika dan Ilmu Pengetahuan Alam IPB

\#Jl. Kamper Kampus IPB Dramaga Bogor 16680

\begin{abstract}
ABSTRAK
Tujuan penelitian ini adalah mengidentifikasi dan menganalisis model bisnis di Supermarket XYZ, kemudian memberikan rekomendasi strategi prioritas sebagai penyempurnaan dari model bisnis Supermarket XYZ secara lebih sistimatik, spesifik, unik dan relevan dengan kondisi bisnisnya saat ini. Penelitian ini menggunakan metode analisis deskriptif. Alat analisis yang digunakan dalam penelitian ini adalah model bisnis kanvas (MBK), matriks evaluasi faktor eksternal (EFE), matriks evaluasi faktor internal (IFE), matriks internal eksternal (IE), matriks SWOT, dan kombinasi proses hirarki analitik (AHP) dan analisis SWOT yang disebut dengan AWOT. Pada elemen saluran didapatkan prioritas strategi dengan skor tertinggi adalah strategi SO yaitu pengembangan food court untuk memberikan pengalaman berbelanja pelanggan. Kemudian, prioritas strategi dari elemen hubungan pelanggan dengan skor tertinggi adalah pada strategi ST yaitu kerjasama dengan pihak ketiga untuk pengembangan program promosi bersama. Terakhir, prioritas strategi dari elemen aktivitas kunci dengan skor tertinggi adalah strategi WO yaitu pelatihan dan pengembangan karyawan. Elemen model bisnis kanvas yang dipilih dan strategi yang ditentukan dapat menjadi dasar untuk pengembangan model bisnis Supermarket XYZ di masa mendatang.
\end{abstract}

Kata kunci: AHP, bisnis model kanvas, ritel supermarket, SWOT

\section{ABSTRACT}

The purpose of the research is to identify and analyze the business model in Supermarket XYZ, then give recommendation of priority strategy as perfection of Supermarket XYZ business model to more systematic, specific, unique and relevant to current business condition. This research uses descriptive analysis method. The analytical tool used is business model canvass (BMC), the external factor evaluation matrix (EFE), internal factor evaluation matrix (IFE), external internal matrix (IE), and the combination between strength, weakness, opportunity, threat (SWOT), and analytical hierarchy process (AHP) called AWOT. The result was obtained based on the result of AWOT analysis, the priority strategy of the channel element with the highest score is SO strategy, to develop a food court to provide a customer shopping experience. Priority strategy of the customer relationship element is ST strategy, cooperation with the third parties for the development of joint promotion programs. Finally, priority strategy of the key activities element is WO strategy, training and development program. The Selected BMC element and the specified strategy can be the basis for the development of the Supermarket XYZ business model in the future.

Key words: AHP, business model canvass, retail supermarket, SWOT

\footnotetext{
*) Korespondensi:

Jl. Jend Sudirman Kav 52-53 Jakarta Pusat, email: jack04absalom@gmail.com
} 


\section{PENDAHULUAN}

Industri ritel modern di Indonesia mengalami pertumbuhan yang pesat dalam beberapa tahun terakhir. Pertumbuhan ritel modern ini salah satunya dipengaruhi oleh pergeseran pola perilaku konsumen kelas menengah dan atas di Indonesia yang tinggal di perkotaan yang tadinya berbelanja di pasar tradisional bergeser menjadi ke pasar modern dalam memenuhi kebutuhan pokoknya. Secara umum tempat belanja yang nyaman, bersih dan keamanan pangan yang terjamin merupakan salah satu faktor utama yang menjadi pilihan tempat berbelanja masyarakat kelas menengah atas di perkotaan pada saat ini. Menurut survei, sebagian konsumen yang tinggal di perkotaan mulai terbiasa untuk memerhatikan tempat dan jenis produk yang akan dibeli. Responden menganggap bahwa tempat dan produk yang dibeli punya pengaruh yang besar dalam pengambilan keputusan pembelian produk makanan (Rahanta, 2012).

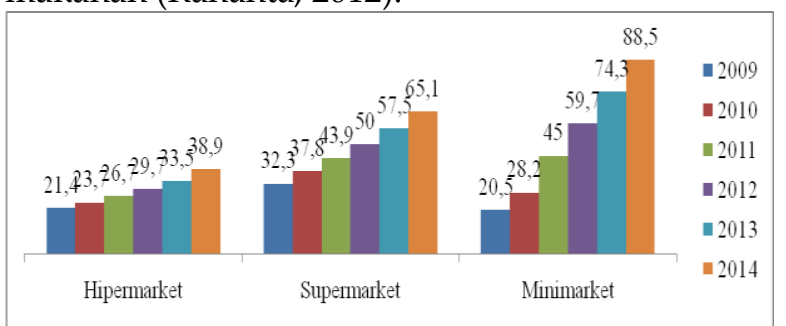

Gambar 1. Penjualan Ritel Modern 2009-2014 di Indonesia dalam triliun rupiah

Sumber: Euromonitor USDA 2015.

Supermarket XYZ adalah sebuah perusahaan yang bergerak di bidang ritel supermarket. Pilar kategori dari supermarket ini adalah produk-produk perishable seperti daging, ikan, buah dan sayur, serta produk-produk dalam kemasan. Supermarket XYZ berada di daerah Cibubur-Cileungsi, pada kawasan tersebut terdapat beberapa area perumahan besar, seperti Legenda Wisata, Kota Wisata, Puri Sriwedari, Raffles Hills, Citragrand, Metland dan lain-lain. Hal ini selain memiliki potensi yang sangat besar dari sisi pertumbuhan konsumennya, namun juga diiringi oleh kompetisi di industri ritel yang semakin ketat, khususnya perkembangan ritel supermarket dan toko buah yang cukup pesat di area tersebut.

Keadaan di atas tentunya menjadi keuntungan sekaligus tantangan Supermarket XYZ dalam upaya mengembangkan usahanya. Sebagai pemain baru pada industri ritel supermarket di Indonesia, maka Supermarket XYZ harus senan- tiasa mengoptimalkan sumber dayanya secara cermat untuk terus berinovasi dan berkreasi. Saat ini, dengan jumlah toko yang terbatas dan persaingan bisnis yang semakin sengit, maka Supermarket XYZ harus senantiasa memanfaatkan dan mengoptimalkan pemanfaatan sumber daya yang ada dengan bisnis model yang sesuai dengan karakter bisnisnya.

Dalam menilai dan memahami bisnisnya, maka konsep bisnis model kanvas yang ditawarkan oleh Osterwalder dan Pigneur (2014) merupakan salah satu model strategi bisnis yang patut dipertimbangkan oleh Supermarket XYZ untuk terus berinovasi dan berkreasi dalam mempertahankan eksistensi bisnis bagi perusahaannya. Dalam hal ini, elemen-elemen dalam model bisnis kanvas (MBK) yang mencakup segmen pelanggan, proposisi nilai, saluran, hubungan pelanggan, alur pendapatan, sumberdaya kunci, aktivitas kunci, mitra kunci, dan struktur biaya dapat dijadikan salah satu model bisnisnya.

Tujuan penelitian adalah mengidentifikasi dan menganalisis kondisi bisnis di Supermarket XYZ dengan pendekatan model bisnis kanvas (MBK) dan menentukan alternatif strategi prioritasnya.

\section{METODE PENELITIAN}

Penelitian ini dilaksanakan di supermarket XYZ Cileungsi, Bogor dari bulan Juni hingga Juli 2017. Metode penelitian menggunakan analisis deskriptif dengan model bisnis kanvas (MBK) yang menggunakan data primer dan sekunder. Data primer diperoleh dari kuesioner dan wawancara, sedangkan data sekunder diperoleh dari studi dokumentasi berbagai sumber yang relevan. Metode pengumpulan data menggunakan metode wawancara, observasi dan studi dokumentasi. Teknik penetapan responden menggunakan purposive sampling. Jumlah responden dipilih sebanyak lima orang berdasarkan kompetensi masing-masing dalam bisnis supermarket $X Y Z$, baik internal maupun eksternal perusahaan, yaitu manajer merchandising fresh, manajer merchandising grocery, kepala toko, wakil kepala toko, general manager suplier supermarket XYZ.

Alat analisis dalam penelitian ini menggunakan model bisnis kanvas (MBK), matriks EFE, matriks IFE, matriks IE, matriks SWOT dan AWOT (kombinasi AHP dan SWOT). Dengan kerangka pemikiran penelitian seperti ditunjukkan pada Gambar 2. 


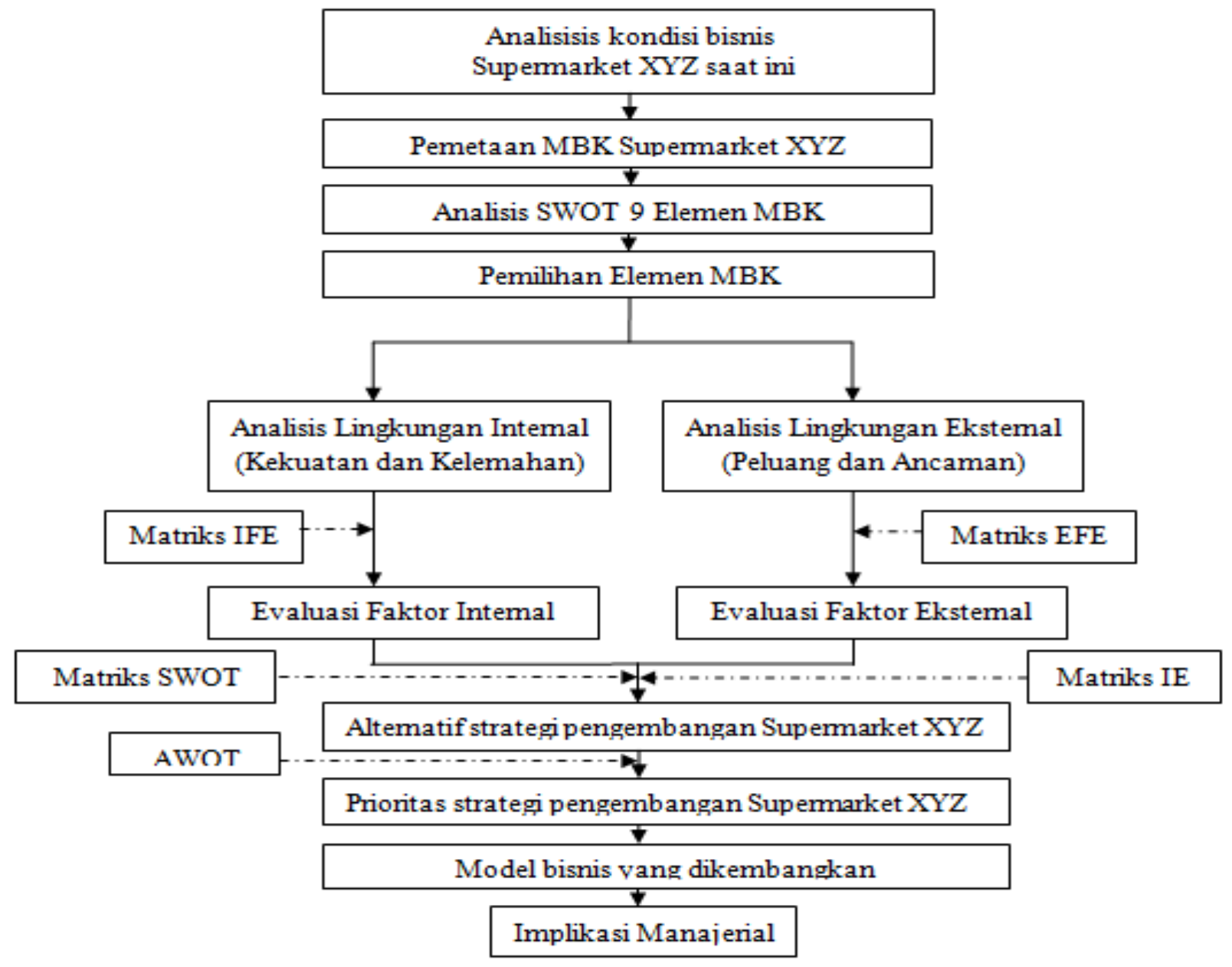

Gambar 2. Kerangka pemikiran penelitian

Dalam penelitian ini, penentuan hierarki prioritas dari alternatif strategi AHP yang diperoleh dari matriks SWOT terdiri dari empat tingkatan (Osuna, 2007), yaitu:

a. Tujuan (Goal) dari satu elemen yang ingin dicapai.

b. Kriteria (Objectives) dari empat kelompok faktor yang didefinisikan melalui teknik SWOT.

c. Sub-kriteria (Factors) dari faktor-faktor kunci yang termasuk dalam kelompok faktor yang didefinisikan oleh teknik SWOT.

d. Alternatif strategi (Proposed Strategies) yang harus dibandingkan dan dievaluasi, pada akhirnya alternatif strategi yang memiliki bobot tertinggi yang akan dipilih menjadi alternatif strategi prioritas dalam penelitian ini.

Untuk merumuskan prioritas dari beberapa alternatif strategi didapat dengan persamaan nilai global relatif dari strategi $\mathrm{j}(\mathrm{Vj})$.

$$
V_{j}=w_{S} \sum_{i=1}^{i=m s} w_{S i} U_{S i, j}+w_{W} \sum_{i=1}^{i=m w} w_{W i} U_{W i, j}+w_{O} \sum_{i=1}^{i=m o} w_{O i} U_{O i, j}+w_{T} \sum_{i=1}^{i=m t} w_{T i} U_{T i, j}
$$

Dari persamaan diatas strategi yang paling prioritas adalah strategi dengan nilai $V j$ tertinggi.

\section{HASIL DAN PEMBAHASAN}

\section{Model Bisnis Kanvas Supermarket XYZ}

Supermarket XYZ merupakan sebuah toko yang terletak di perumahan Legenda Wisata Cileungsi, Bogor. Supermarket ini pertama kali dibuka pada bulan Oktober 2016 untuk memenuhi kebutuhan pokok harian masyarakat sekitar. Produk-produk yang dijualnya adalah produk ritel eceran berupa kebutuhan dasar rumah tangga sehari-hari, seperti produk daging segar, ikan, sayur dan buah, produk susu dan turunannya, produk beku, serta produk dalam kemasan baik makanan maupun non makanan. Selain itu, terdapat beberapa toko penyewa di dalam area supermarket, diantaranya toko roti, apotik, gerai kopi, serta area makanan siap saji.

Dari hasil observasi dan wawancara yang dilakukan dengan responden penelitian, secara geografis mayoritas segmen pelanggan supermarket XYZ bertempat tinggal di area perumahan KW dan LW yang berada di sekitar area toko. Dari jenis pekerjaan, sebagian besar pelanggan adalah berprofesi sebagai ibu rumah tangga, 
pegawai swasta dan jenis pekerjaan lain yang beragam. Proposisi nilainya adalah akses dan kenyamanan. Saluran utama yang digunakan adalah fisik toko sebagai saluran fisik langsung dan saluran katalog promosi, SMS/WA dan email blast sebagai saluran tidak langsung.

Program membership merupakan alat utama dalam membangun hubungan pelanggan. Aliran pendapatan utama terdiri dari tiga jenis pendapatan, yaitu penjualan aset, sewa dan komisi. Aktivitas kunci Supermarket XYZ adalah pada bidang operasi jasa yang fokus utamanya adalah pengelolaan dan penjualan produk barang dagangan atau eceran. Sementara, kemitraan kuncinya adalah kemitraan pembeli-pemasok dalam rangka mensuplai produk-produk dagangan eceran yang akan dijual kembali kepada pelanggannya. Model kemitraan pembeli-pemasok yang dikembangkan terdiri dari tiga jenis kerjasama, yaitu kerjasama beli putus, bagi hasil atau konsinyasi dan kerjasama sewa. Struktur biayanya adalah struktur biaya yang terpacu biaya dengan perpaduan antara biaya tetap dan biaya variabel. Untuk pengeluaran biaya tetap terdiri dari gaji karyawan, sewa gedung toko. Untuk biaya variabel terdiri dari biaya listrik, air dan gas, serta biaya non trade. Secara umum pemetaan Supermarket XYZ melalui sembilan elemen bisnis model dapat ditunjukkan seperti Gambar 3.

\section{Analisis SWOT}

Model bisnis kanvas supermarket XYZ yang telah dipetakan kemudian dilakukan analisis
SWOT melalui survei, observasi maupun kajian internal.

Survei dilakukan melalui kuesioner dengan metode wawancara baik kepada pihak internal maupun eksternal. Hasil analisis SWOT elemenelemen model bisnis kanvas Supermarket XYZ ditunjukkan pada Tabel 1.

\section{Pengembangan MBK Supermarket XYZ}

Untuk pengembangan model bisnis supermarket $X Y Z$, maka dipilih dan ditentukan tiga elemen MBK yang akan dikembangkan. Hasil wawancara dan analisis responden ahli dan

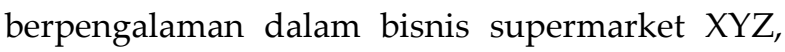
maka dipilih tiga elemen MBK, yaitu saluran, hubungan pelanggan dan aktivitas kunci.

Dasar pemilihannya adalah elemen saluran merupakan sarana yang sangat penting dalam menyampaikan dan mengomunikasikan proposisi nilai kepada pelanggan sekaligus sebagai sarana komunikasi dan interaksi terhadap keseluruhan aktivitas yang dilakukan oleh Supermarket XYZ. Kemudian dengan elemen hubungan pelanggan yang baik, maka berpotensi untuk meningkatkan akuisisi pelanggan, mempertahankan pelanggan yang loyal dan pada akhirnya dapat meningkatkan arus pendapatan. Terakhir, elemen aktivitas kunci yang optimal dapat memberikan proposisi nilai dan brand image yang positif, yang bermuara pada peningkatan arus pendapatan bagi supermarket XYZ.

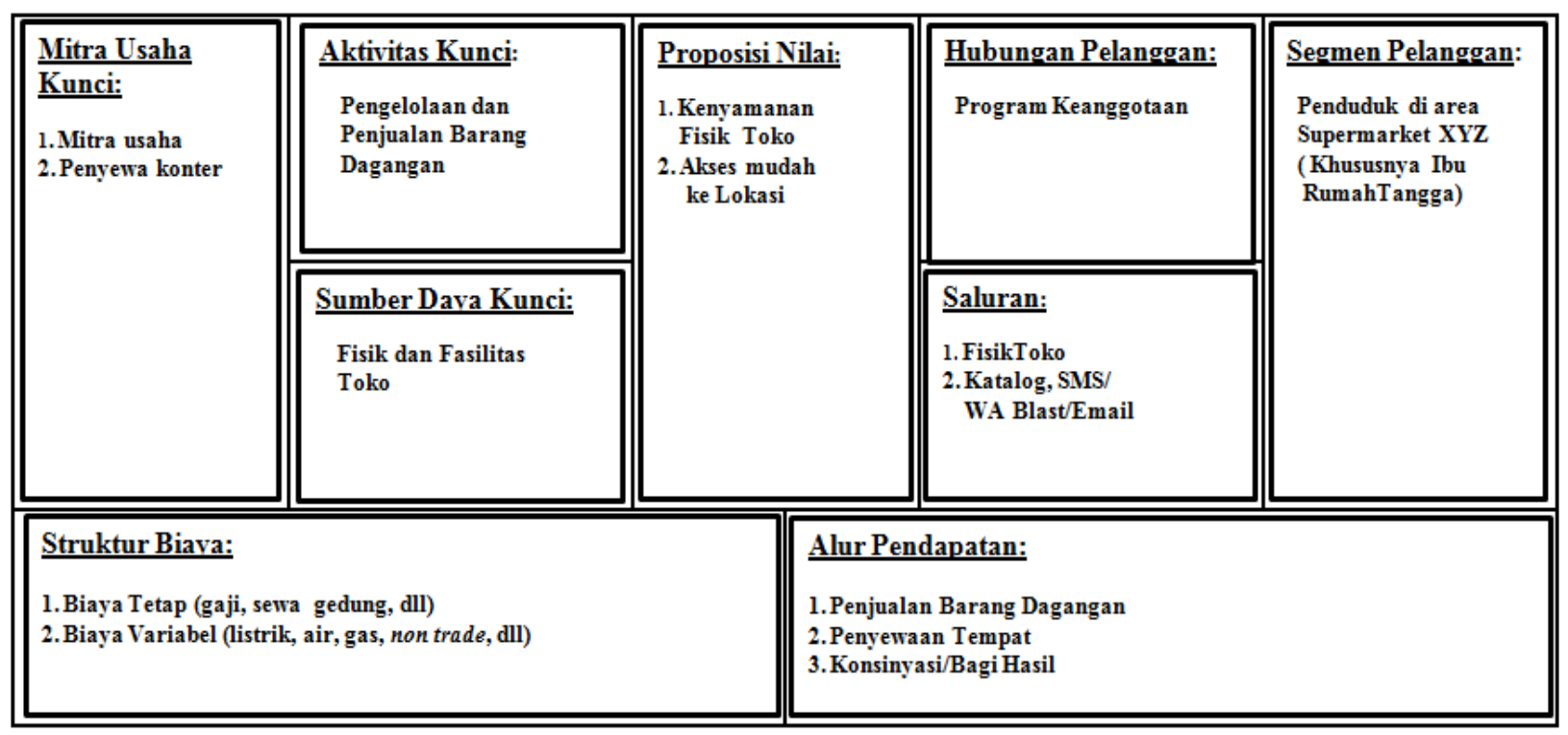

Gambar 3. Pemetaan awal Model Bisnis Kanvas Supermarket XYZ 
Tabel 1. Analisis SWOT Model Bisnis Kanvas Supermarket XYZ

\begin{tabular}{|c|c|c|c|c|}
\hline Aspek & Kekuatan (S) & Kelemahan (W) & Peluang $(\mathrm{O})$ & Ancaman (T) \\
\hline $\begin{array}{l}\text { Segmen } \\
\text { Pelanggan }\end{array}$ & $\begin{array}{l}\text { Basis data pelanggan } \\
\text { Pasar tersegmentasi. }\end{array}$ & Keluhan pelanggan. & $\begin{array}{l}\text { Potensi area Cibubur. } \\
\text { Pengembangan } \\
\text { produk/layanan. }\end{array}$ & $\begin{array}{l}\text { Alternatif pilihan } \\
\text { belanja. Range } \\
\text { produk pesaing } \\
\text { lebih baik }\end{array}$ \\
\hline $\begin{array}{l}\text { Proposisi } \\
\text { Nilai }\end{array}$ & $\begin{array}{l}\text { Selaras pelanggan. } \\
\text { Tren pasar sesuai. }\end{array}$ & $\begin{array}{l}\text { Lokasi di area } \\
\text { perumahan. }\end{array}$ & $\begin{array}{l}\text { Inovasi Terknologi } \\
\text { informasi. }\end{array}$ & $\begin{array}{l}\text { Akses pesaing } \\
\text { mudah. }\end{array}$ \\
\hline $\begin{array}{l}\text { Alur } \\
\text { Pendapatan }\end{array}$ & $\begin{array}{l}\text { Pendapatan } \\
\text { berkelanjutan. } \\
\text { Pembelian berulang. } \\
\text { Penjualan terprediksi. }\end{array}$ & $\begin{array}{l}\text { Margin dan skala } \\
\text { ekonomi kecil. }\end{array}$ & $\begin{array}{l}\text { Pengembangan arus } \\
\text { pendapatan. } \\
\text { Pendapatan dikonversi. }\end{array}$ & $\begin{array}{l}\text { Harga jual dan } \\
\text { margin terancam. }\end{array}$ \\
\hline Saluran & $\begin{array}{l}\text { Lokasi terjangkau. } \\
\text { Pengalaman Berbelanja. } \\
\text { Terstandarisasi. } \\
\text { Efektif dan efisien. }\end{array}$ & $\begin{array}{l}\text { Brand awareneness } \\
\text { rendah. }\end{array}$ & $\begin{array}{l}\text { Saluran/mitra baru. } \\
\text { Mengintegrasikan } \\
\text { saluran. } \\
\text { Efektivitas/Efisiensi. } \\
\text { Margin Penjualan. }\end{array}$ & $\begin{array}{l}\text { Pesaing } \\
\text { mengancam } \\
\text { saluran. } \\
\text { Saluran pesaing } \\
\text { lebih baik. } \\
\text { Saluran tidak } \\
\text { relevan. }\end{array}$ \\
\hline $\begin{array}{l}\text { Hubungan } \\
\text { Pelanggan }\end{array}$ & $\begin{array}{l}\text { Data pelanggan. } \\
\text { Bantuan khusus. } \\
\text { Promosi khusus. } \\
\text { Program khusus. }\end{array}$ & $\begin{array}{l}\text { Bantuan khusus } \\
\text { pengiriman. }\end{array}$ & $\begin{array}{l}\text { Hubungan komunitas. } \\
\text { Personalisasi. } \\
\text { Jumlah pelanggan. }\end{array}$ & $\begin{array}{l}\text { Pesaing dengan } \\
\text { pihak ketiga. }\end{array}$ \\
\hline $\begin{array}{l}\text { Aktivitas } \\
\text { Kunci }\end{array}$ & $\begin{array}{l}\text { Harga value for money. } \\
\text { Kerjasama pelanggan. } \\
\text { Kerjasama mitra usaha. }\end{array}$ & $\begin{array}{l}\text { Pelatihan karyawan. } \\
\text { Aktifitas kunci } \\
\text { mudah ditiru. }\end{array}$ & $\begin{array}{l}\text { Standarisasi proses. } \\
\text { Bisnis proses\&SOP. } \\
\text { Mengembangkan } \\
\text { sistim TI. }\end{array}$ & $\begin{array}{l}\text { Aktivitas kunci } \\
\text { mudah ditiru. } \\
\text { Kualitas tidak } \\
\text { terstandarisasi. } \\
\text { Dipengaruhi oleh } \\
\text { mitra usaha. } \\
\end{array}$ \\
\hline $\begin{array}{l}\text { Sumber Daya } \\
\text { Kunci }\end{array}$ & $\begin{array}{l}\text { Konsep dan fasilitas } \\
\text { toko sesuai segmen. }\end{array}$ & $\begin{array}{l}\text { Pengembangan } \\
\text { Sumber daya. }\end{array}$ & $\begin{array}{l}\text { Optimalisasi } \\
\text { Sumberdaya kunci. } \\
\text { Kerjasama mitra usaha. }\end{array}$ & $\begin{array}{l}\text { Sumberdaya kunci } \\
\text { terbatas. }\end{array}$ \\
\hline $\begin{array}{l}\text { Mitra Usaha } \\
\text { Kunci }\end{array}$ & $\begin{array}{l}\text { Kerjasama/kolaborasi } \\
\text { mitra. } \\
\text { Kerjasama inovasi } \\
\text { produk }\end{array}$ & $\begin{array}{l}\text { Skala ekonomi } \\
\text { terbatas. }\end{array}$ & $\begin{array}{l}\text { Kolaborasi mitra usaha. } \\
\text { Manfaat saluran mitra } \\
\text { usaha. } \\
\text { Mitra usaha } \\
\text { melengkapi Proposis } \\
\text { Nilai. }\end{array}$ & $\begin{array}{l}\text { Mitra usaha } \\
\text { berkolaborasi } \\
\text { dengan pesaing. }\end{array}$ \\
\hline $\begin{array}{l}\text { Struktur } \\
\text { Biaya }\end{array}$ & $\begin{array}{l}\text { Pembelian barang } \\
\text { sesuai. } \\
\text { Pengeluaran biaya } \\
\text { terprediksi. }\end{array}$ & $\begin{array}{l}\text { Struktur biaya tidak } \\
\text { sesuai. }\end{array}$ & $\begin{array}{l}\text { Optimalisasi Pembelian } \\
\text { barang. Efisiensi biaya } \\
\text { operasional. }\end{array}$ & $\begin{array}{l}\text { Tidak dapat } \\
\text { menekan biaya. }\end{array}$ \\
\hline
\end{tabular}

\section{Analisis Lingkungan Eksternal dan Internal}

Elemen strategis pertama yang dikembangkan adalah elemen saluran. Dalam menganalisis lingkungan eksternal digunakan matriks EFE dan diperoleh skor 3,005 (Tabel 2). Hal ini menunjukkan bahwa Supermarket XYZ efektif dalam menggunakan strategi yang memanfaatkan peluang eksternal untuk menghindari ancaman eksternal dalam memaksimalkan elemen salurannya. Pada hasil matriks EFE, mengintegrasikan saluran (toko fisik, tenaga penjual, media komunikasi) dengan lebih baik memiliki skor terbesar pada faktor peluang sebesar 0,594. Selain itu, pada faktor ancaman, saluran terancam menjadi tidak relevan dengan perilaku pelanggan memiliki skor tertinggi dengan 0,281. Hasil tersebut menunjukkan bahwa media komunikasi yang digunakan saat ini seperti katalog, SMS, WA serta email blast perlu untuk dikembangkan dan mengadaptasi kebutuhan pelanggan. Perilaku pelanggan dimana belanja masih dijadikan aktivitas rekreasi harus menjadi pertimbangan dalam pengembangan elemen saluran Supermarket XYZ. Dalam menganalisis lingkungan internal digunakan matriks IFE dan diperoleh skor 2,681 (Tabel 3). Hasil ini menunjukkan bahwa Supermarket XYZ efektif 
Tabel 2. Matriks EFE saluran Supermarket XYZ

\begin{tabular}{|c|c|c|c|}
\hline Faktor Eksternal & Bobot & Peringkat & Skor \\
\hline $\begin{array}{lcc} & \text { Peluang } \\
\text { Menemukan dan } & \text { mengembangkan saluran/mitra baru } \\
\text { lainnya untuk pelayanan pelanggan yang lebih baik. }\end{array}$ & 0,148 & 3,8 & 0,564 \\
\hline $\begin{array}{l}\text { Mengintegrasikan saluran (toko fisik, tenaga penjual, media } \\
\text { komunikasi) dengan lebih baik. }\end{array}$ & 0,148 & 4 & 0,594 \\
\hline Meningkatkan efisiensi dan efektivitas salurannya & 0,148 & 3,8 & 0,564 \\
\hline Meningkatkan margin penjualan dengan saluran yang tepat & 0,141 & 4,0 & 0,563 \\
\hline Ancaman & & & - \\
\hline Pesaing mengancam saluran & 0,133 & 1,4 & 0,186 \\
\hline Pesaing memiliki saluran yang lebih baik & 0,140 & 1,8 & 0,253 \\
\hline $\begin{array}{l}\text { Saluran terancam menjadi tidak relevan dengan pola } \\
\text { perilaku pelanggan }\end{array}$ & 0,140 & 2,0 & 0,281 \\
\hline Total & 1 & & 3,005 \\
\hline
\end{tabular}

Tabel 3. Matriks IFE saluran Supermarket XYZ

\begin{tabular}{|c|c|c|c|}
\hline Faktor Internal & Bobot & Peringkat & Skor \\
\hline \multicolumn{4}{|l|}{ Kekuatan } \\
\hline Lokasi Saluran (fisik toko) dapat dijangkau pelanggan & 0,052 & 4,0 & 0,208 \\
\hline $\begin{array}{l}\text { Saluran memberikan pengalaman berbelanja (arena bermain anak, } \\
\text { toko roti, apotik, gerai kopi) }\end{array}$ & 0,110 & 3,4 & 0,376 \\
\hline Saluran (lokasi dan konsep toko) sesuai dengan segmen pelanggan & 0,117 & 3,6 & 0,422 \\
\hline Saluran (tenaga penjualan, fisik toko) terstandarisasi & 0,110 & 3,0 & 0,331 \\
\hline $\begin{array}{l}\text { Saluran (media komunikasi) efektif dan efisien dalam menjangkau } \\
\text { pelanggan }\end{array}$ & 0,124 & 3,4 & 0,420 \\
\hline \multicolumn{4}{|l|}{ Kelemahan } \\
\hline $\begin{array}{l}\text { Saluran (tenaga penjual dan media komunikasi) belum dapat } \\
\text { menyampaikan proposisi nilainya }\end{array}$ & 0,116 & 2,0 & 0,233 \\
\hline $\begin{array}{l}\text { Saluran (tenaga penjual dan media komunikasi) belum memberikan } \\
\text { brand awareneness }\end{array}$ & 0,123 & 2,0 & 0,246 \\
\hline $\begin{array}{l}\text { Saluran belum terintegrasi dengan baik (media komunikasi dan } \\
\text { eksekusi di toko) }\end{array}$ & 0,123 & 2,0 & 0,247 \\
\hline Saluran (tenaga penjual) belum memberikan dukungan purnajual & 0,123 & 1,6 & 0,197 \\
\hline Total & 1 & & 2,681 \\
\hline
\end{tabular}

dalam menjalankan strategi yang memaksimalkan kekuatan internal dan meminimalisasi kelemahan internal untuk memberikan saluran yang efektif kepada pelanggan.

Hasil analisis EFE dan IFE pada elemen saluran kemudian digabungkan pada matriks IE sehingga elemen saluran berada pada kuadran IV atau kuadran tumbuh dan kembangkan. Hasil ini menunjukkan bahwa Supermarket XYZ berada pada posisi bersaing yang kuat, tetapi berada pada segmen bisnis yang tumbuh rata-rata. Menurut David (2009), strategi yang tepat adalah strategi intensif (penetrasi pasar, pengembangan pasar, dan pengembangan produk).

Elemen strategis kedua yang dikembangkan adalah hubungan pelanggan. Dalam menganalisis lingkungan eksternal hubungan pelanggan, digunakan matriks EFE dan diperoleh skor
2,947. Hal ini mengindikasikan bahwa kondisi eksternal Supermarket XYZ cukup mampu dalam memanfaatkan peluang untuk menghindari ancaman yang dihadapi. Hasil dari matriks EFE pada faktor peluang menunjukkan bahwa potensi untuk menambah jumlah anggota pelanggan, meningkatkan personalisasi melalui produk dan layanan serta berfokus melayani pelanggan yang menguntungkan memiliki skor tertinggi dengan skor 0,580. Dengan basis data pelanggan yang dimiliki, Supermarket XYZ masih berpotensi untuk menambah jumlah anggota pelanggan dengan cara pengembangan produk maupun layanan yang diberikan kepada pelanggannya.

Disisi lain, pada faktor ancaman, pesaing memiliki program hubungan pelanggan yang lebih baik memiliki skor tertinggi dengan 0,261. Salah satu kendala utama dalam pengembangan 
program hubungan pelanggan pada Supermarket XYZ adalah keterbatasan skala ekonomi bisnisnya, sehingga ketika ingin mengadakan kerjasama dan bernegosiasi dengan mitra usaha, nilai tawarnya dirasakan kurang jika dibandingkan dengan pesaing.

Dalam menganalisis lingkungan internal pada elemen hubungan pelanggan digunakan matriks IFE dan diperoleh skor 2,854. Hal ini menunjukkan kondisi internal supermarket $\mathrm{XYZ}$ relatif mampu menggunakan kekuatan untuk mengantisipasi kelemahan yang dimiliki. Pada faktor kekuatan memiliki program keanggotaan dan data pelanggan serta memiliki program promosi khsusus member memiliki nilai skor tertinggi yaitu 0,604 . Hasil tersebut menunjukkan bahwa program terbukti menjadi kekuatan utama Supermarket XYZ dalam membina hubungan pelanggan, mempertahankan pelanggan loyal serta mengakuisisi pelanggan baru.

Sementara pada faktor kelemahan belum menciptakan nilai bersama dengan para pelanggannya memiliki nilai skor tertinggi sebesar 0,320. Pengembangan program ini bisa dilakukan dalam bentuk program yang memfasilitasi pelanggan seperti membuat arisan, customer gathering, kelas memasak, acara bersama sekolah, dimana Supermarket XYZ dapat menjadi tempat diadakannya kegiatan tersebut dan menjadi sponsor dalam program-program tersebut. Hasil analisis EFE dan IFE pada elemen hubungan pelanggan kemudian digabungkan pada matriks IE, sehingga berada pada posisi kuadran V. Menurut David (2009), rekomendasi untuk divisi yang masuk dalam sel $\mathrm{V}$ dapat digambarkan sebagai strategi jaga dan pertahankan. Penetrasi pasar dan pengembangan produk adalah dua strategi yang umumnya digunakan pada kuadran tersebut.

Elemen strategis terakhir yang dikembangkan adalah aktivitas kunci. Dalam menganalisis lingkungan eksternal pada elemen aktivitas kunci digunakan matriks EFE dan diperoleh skor 2,710. Artinya, kondisi eksternal Supermarket XYZ cukup mampu dalam memanfaatkan peluang untuk menghindari ancaman yang dihadapi. Hasil dari matriks EFE menunjukkan bahwa penetapan bisnis proses dan SOP memiliki skor tertinggi pada faktor peluang dengan nilai 0,711 . Diikuti dengan standarisasi aktivitas kunci dengan skor 0,635. Kedua faktor di atas dinilai perlu mengingat Supermarket XYZ merupakan bisnis baru yang akan berkembang, namun belum diimbangi dengan aturan dan ketentuan yang jelas dalam operasionalisasinya, sehingga Sistem Operasional dan Prosedur (SOP) serta standar penanganan produk menjadi penting untuk dilakukan sebagai dasar dalam pengembangan strategi Supermarket XYZ ke depannya.

Pada faktor ancaman, kualitas aktivitas kunci pesaing lebih baik memiliki skor tertinggi dengan skor 0,320. Kemudian diikuti dengan aktivitas kunci sangat dipengaruhi oleh mitra usahanya yang memperoleh skor 0,302. Hal ini menunjukkan bahwa jika Supermarket XYZ dibandingkan dengan pesaing dalam hal standarisasi operasionalnya, maka terlihat bahwa pesaing lebih baik karena telah memiliki standarisasi operasional maupun pelayanan. Di samping itu, mengingat skala ekonomi Supermarket XYZ yang terbatas, maka kualitas produk dan kontinuitas produk sangat dipengaruhi oleh mitra usahanya.

Pada faktor lingkungan internal elemen aktivitas kunci, matriks IFE memperoleh skor 2,80. Hal ini mengindikasikan kondisi internal Supermarket XYZ relatif rata-rata dalam mengoptimalkan kekuatannya untuk mengantisipasi kelemahan yang dimiliki. Pada faktor kekuatan aktivitas kunci harga barang dagangan value for money memiliki skor tertinggi dengan perolehan 0,429. Hal ini menunjukkan faktor harga merupakan faktor kekuatan terpenting bagi Supermarket XYZ dan karena faktor hargalah yang membuat pertumbuhan pelanggan dan transaksi, serta menghasilkan aliran pendapatan bagi usahanya

Hasil analisis EFE dan IFE pada aktivitas kunci kemudian digabungkan pada matriks IE, sehingga berada pada posisi kuadran V. Menurut David (2009), rekomendasi untuk divisi yang masuk dalam sel $\mathrm{V}$ dapat digambarkan sebagai strategi jaga dan pertahankan. Penetrasi pasar dan pengembangan produk adalah dua strategi yang juga biasanya digunakan pada kuadran tersebut.

\section{Perumusan Alternatif Strategi dengan Analisis SWOT}

Menurut Rangkuti (2013), matriks SWOT merupakan alat analisis yang penting untuk mencocokkan dan mengembangkan empat tipe strategi, yaitu: SO (strengths-opportunities), WO (weaknesses-opportunities), ST (strengths-threats), WT (weaknesses-opportunities). Hasil identifikasi faktor-faktor lingkungan eksternal dan internal yang membentuk matriks internal eksternal, kemudian disusun matriks SWOT. Dari matriks 
SWOT tersebut dihasilkan beberapa alternatif strategi (Gambar 4) pada elemen saluran sebagai berikut: (a) strategi SO1 (Strengths-Opportunities) mengembangkan food court dengan ragam makanan yang memberikan pilihan kepada pelanggan; (b) strategi $\mathrm{SO} 2$ bekerjasama dengan food blogger dalam memperkenalkan dan mempromosikan Supermarket XYZ; (c) strategi ST (StrengthsThreats) strategi melakukan standarisasi proses operasi di toko dengan program inspired the customers; (d) strategi WO1 (Weaknesses-Opportunities) strategi membuat website untuk lebih memasarkan produk dan meningkatkan jumlah pelanggan; (e) strategi WO2 strategi membuat aplikasi pesan ambil untuk menjangkau pelanggan yang memiliki tempat tinggal yang jauh dan waktu yang terbatas; (f) strategi WT (Weaknesses-Threats) adalah strategi bekerjasama dengan pihak ketiga untuk penjualan produk online dan pesan antar produk.

Pada elemen hubungan pelanggan, perumusan alternatif strategi yang dihasilkan adalah sebagai berikut: (a) strategi SO1 (StrengthsOpportunities) strategi mengembangkan program after sales service; (b) $\mathrm{SO} 2$ strategi berkolaborasi dengan komunitas pelanggan dengan membuat agenda program dan aktivitas bersama; (c) strategi ST1 (Strengths-Threats) strategi mengembangkan program kerjasama dengan pihak ketiga untuk memberikan promosi khusus; (d) ST2 strategi bekerjasama dengan mitra usaha untuk pengembangan produk; (e) strategi WO1 (Weaknesses-Opportunities) strategi bekerjasama dengan mitra usaha untuk mengembangkan program pemasaran khusus; (f) strategi WO2 adalah membuat program spesial untuk pelanggan yang merayakan hari-hari khusus; (g) strategi WT (Weaknesses-Threats) strategi mengembangkan program delivery service.

Pada elemen aktivitas kunci, perumusan alternatif strategi yang dihasilkan yaitu: (a) strategi SO1 (Strengths-Opportunities) strategi melakukan standarisasi penanganan produk; (b) $\mathrm{SO} 2$ strategi mengembangkan sistim pemesanan; (c) strategi ST1 (Strengths-Threats) strategi melakukan pengembangan produk khusus maupun diferensiasi; (d) ST2 strategi melakukan survei bulanan kepada pelanggan; (e) strategi WO1 (Weaknesses-Opportunities) strategi pelatihan bagi karyawan mengenai SOP dan bisnis proses; (f) strategi $\mathrm{WO} 2$ ialah strategi melakukan kerjasama kemitraan strategis dengan mitra usaha, khususnya dalam proses perencanaan produksi, pendistribusian sampai penjualan; dan (g) WT (Weaknesses-Threats) strategi melakukan standarisasi proses operasi dengan membuat Sistim Operasional dan Prosedur (SOP).

\section{Penentuan Prioritas Strategi dengan SWOT}

Dari faktor lingkungan eksternal dan internal yang membentuk matriks internal dan eksternal, kemudian disusunlah matriks SWOT. Dari matriks SWOT tersebut dihasilkan beberapa strategi alternatif yang kemudian akan diolah melalui kombinasi antara AHP-SWOT dan menghasilkan hirarki integrasi pada elemen saluran. Pada elemen saluran (Tabel 4) bobot tertinggi SWOT terdapat pada faktor kekuatan sebesar 0,515, dengan consistency ratio (CR) 0,06. Sementara hasil perhitungan bobot dan prioritas (Tabel 5) menghasilkan skor tertinggi pada prioritas strategi (SO), yaitu mengembangkan food court, dengan nilai sebesar 0,397. Hal ini menunjukkan bahwa strategi tersebut menjadi prioritas utama dalam pengembangan saluran di Supermarket XYZ. Strategi ST, melakukan standarisasi proses dengan nilai 0,301 . Strategi WT bekerjasama penjualan online dengan nilai 0,214 . Strategi WO membuat web site dengan skor 0,088 .

Tabel 4. Bobot hasil analisis SWOT pada elemen saluran

\begin{tabular}{clc}
\hline No & Faktor & Bobot \\
\hline 1 & Kekuatan $(\mathrm{S})$ & 0,515 \\
2 & Kelemahan $(\mathrm{W})$ & 0,087 \\
3 & Peluang $(\mathrm{O})$ & 0,213 \\
4 & Ancaman $(\mathrm{T})$ & 0,184 \\
\hline
\end{tabular}

Pada elemen hubungan pelanggan bobot tertinggi pada SWOT terdapat pada faktor kekuatan sebesar 0,519 dengan consistency ratio (CR) 0,02. Hasil perhitungan bobot dan prioritas pada elemen hubungan pelanggan menghasilkan skor tertinggi pada prioritas strategi (ST) kerjasama promosi dengan pihak ketiga dengan skor sebesar 0,395. Strategi tersebut dapat menjadi prioritas utama dalam pengembangan elemen hubungan pelanggan di Supermarket XYZ. Diikuti dengan strategi $\mathrm{SO}$, program after sales service dengan nilai 0,276 . Strategi WT standarisasi SOP dengan nilai 0,170. Strategi WO kerjasama dengan mitra usaha mendapatkan skor senilai 0,159 .

Terakhir, pada elemen aktivitas kunci, bobot tertinggi pada SWOT elemen aktivitas kunci terdapat pada faktor kekuatan sebesar 0,426 dengan consistency ratio (CR) 0,02 . Sementara hasil 
perhitungan bobot dan prioritas menghasilkan prioritas strategi (WO) pelatihan dan pengembangan karyawan dengan nilai sebesar 0,438. Dapat disimpulkan bahwa strategi tersebut menjadi prioritas utama dalam pengembangan elemen aktivitas kunci di Supermarket XYZ. Diikuti dengan strategi ST, pengembangan produk dengan nilai 0,264 . Strategi WT standarisasi SOP dengan nilai 0,170 . Strategi SO standarisasi penanganan produk dengan skor 0,128 . Prioritas strategi pengembangan ketiga elemen MBK

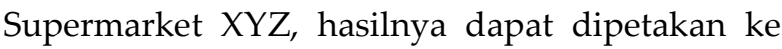
dalam MBK yang telah disempurnakan seperti ditunjukan pada Gambar 5.

Tabel 5. Bobot dan prioritas pada alternatif strategi saluran

\begin{tabular}{clcc}
\hline No & \multicolumn{1}{c}{ Alternatif Strategi } & Bobot & Prioritas \\
\hline 1 & $\begin{array}{l}\text { Mengembangkan Food Court } \\
\text { (SO) }\end{array}$ & 0,397 & 1 \\
2 & $\begin{array}{l}\text { Melakukan standarisasi proses } \\
\text { dengan program Inspired The }\end{array}$ & 0,301 & 2 \\
& $\begin{array}{l}\text { Customers (ST) } \\
\text { Bekerjasama penjualan online } \\
\text { (WT) }\end{array}$ & 0,214 & 3 \\
4 & Membuat website (WO) & 0,088 & 4 \\
\hline
\end{tabular}

\begin{tabular}{|c|c|c|}
\hline Eksternal & $\begin{array}{l}\text { Kekuatan (S) } \\
\text { 1. } \begin{array}{l}\text { Lokasi Saluran (fisik toko) dapat } \\
\text { dijangkau pelanggan }\end{array} \\
\text { 2. } \begin{array}{l}\text { Saluran memberikan pengalaman } \\
\text { berbelanja (arena bermain anak, }\end{array} \\
\text { toko roti, apotik, gerai kopi) } \\
\text { 3. Saluran (lokasi dan konsep toko) } \\
\text { sesuai dengan segmen pelanggan } \\
\text { 4. Saluran (tenaga penjualan, fisik } \\
\text { toko) terstandarisasi } \\
\text { 5. Saluran (media komunikasi) efektif } \\
\text { dan efisien dalam menjangkau } \\
\text { pelanggan }\end{array}$ & $\begin{array}{l}\text { Kelemahan (W) } \\
\text { 1. Saluran (tenaga penjual dan media } \\
\text { komunikasi) belum dapat me- } \\
\text { nyampaikan proposisi nilainya } \\
\text { 2. Saluran (tenaga penjual dan media } \\
\text { komunikasi) belum memberikan } \\
\text { brand awareneness } \\
\text { 3. Saluran belum terintegrasi } \\
\text { dengan baik (media komunikasi } \\
\text { dan eksekusi di toko) } \\
\text { 4. Saluran (tenaga penjual) belum } \\
\text { memberikan dukungan purnajual } \\
\text { kepada pelanggannya }\end{array}$ \\
\hline $\begin{array}{l}\text { Peluang (O) } \\
\text { 1. Dapat menemukan dan mengem- } \\
\text { bangkan saluran/mitra baru lainnya } \\
\text { untuk pelayanan pelanggan yang } \\
\text { lebih baik } \\
\text { 2. Dapat mengintegrasikan saluran } \\
\text { (toko fisik, tenaga penjual, media } \\
\text { komunikasi) dengan lebih baik. } \\
\text { 3. Dapat meningkatkan efisiensi dan } \\
\text { efektivitas salurannya } \\
\text { 4. Dapat meningkatkan margin pen- } \\
\text { jualan dengan saluran yang tepat }\end{array}$ & $\begin{array}{l}\text { Strategi S-O } \\
\text { 1. Mengembangkan food court dengan } \\
\text { ragam makanan yang memberikan } \\
\text { pilihan kepada pelanggan (S1, S2, } \\
\text { S3, O1, O2, O4) } \\
\text { 2. Bekerjasama dengan Food Blogger } \\
\text { dalam memperkenalkan dan mem- } \\
\text { promosikan Supermarket XYZ (S3, } \\
\text { S5, O1, O2, O3) }\end{array}$ & $\begin{array}{l}\text { Strategi W-O } \\
\text { 1. Membuat Web Site untuk lebih } \\
\text { memasarkan produk dan mening- } \\
\text { katkan jumlah pelanggan (W1, W2, } \\
\text { W2, W3) } \\
\text { 2. Membuat Aplikasi Pesan Ambil } \\
\text { untuk Menjangkau Pelanggan } \\
\text { yang memiliki tempat tinggal yang } \\
\text { jauh dan waktu yang terbatas (W1, } \\
\text { W2, W4,01, O4) }\end{array}$ \\
\hline $\begin{array}{l}\text { Ancaman (T) } \\
\text { 1. Pesaing mengancam saluran yang } \\
\text { Supermarket XYZ miliki. } \\
\text { 2. Pesaing memiliki saluran (toko fisik, } \\
\text { tenaga penjual, media komunikasi) } \\
\text { yang lebih baik } \\
\text { 3. Saluran (media komunikasi) teran- } \\
\text { cam menjadi tidak relevan dengan } \\
\text { pola perilaku pelanggan saat ini. }\end{array}$ & $\begin{array}{l}\text { Strategi S-T } \\
\text { Melakukan Standarisasi Proses Operasi } \\
\text { di toko dengan program Inspired the } \\
\text { Customers (W1, W2, W4, O1, O2) }\end{array}$ & $\begin{array}{l}\text { Strategi W-T } \\
\text { Bekerjasama dengan pihak ketiga } \\
\text { untuk penjualan produk online dan } \\
\text { pesan antar produk seperti happy fresh } \\
\text { dan Gojek (W3, W4, T1, T2, T3) }\end{array}$ \\
\hline
\end{tabular}

Gambar 4. Matriks SWOT saluran model bisnis kanvas supermarket XYZ 


\begin{tabular}{|c|c|c|c|c|}
\hline \multirow[t]{2}{*}{$\begin{array}{l}\text { Mitra Usaha } \\
\text { Kunci: } \\
\text { 1.Mitra usaha } \\
\text { 2.Penyewa konter }\end{array}$} & $\begin{array}{l}\text { Aktivitas Kunci: } \\
\text { 1. Pengelolaan dan } \\
\text { Penjualan Barang } \\
\text { Dagangan } \\
\text { 2. Pelatihan Karyawan } \\
\text { 3. Pengembangan Produk }\end{array}$ & \multirow[t]{2}{*}{$\begin{array}{l}\text { Proposisi Nilai: } \\
\text { 1. Kenyamanan } \\
\text { Fisik Toko } \\
\text { 2. Akses mudah } \\
\text { ke Lokasi }\end{array}$} & $\begin{array}{l}\text { Hubungan Pelanggan: } \\
\text { 1.Program Keanggotaan } \\
\text { 2. Kerjasam Promosi Pihak } \\
\text { Ketiga (bank, dsb) } \\
\text { 3.Program After Sales } \\
\quad \text { Service }\end{array}$ & \multirow[t]{2}{*}{$\begin{array}{l}\text { Segmen Pelanggan: } \\
\\
\text { Penduduk di area } \\
\text { XYZ Supermarket } \\
\text { (Khususnya Ibu } \\
\text { RumahTangga) }\end{array}$} \\
\hline & $\begin{array}{l}\text { Sumber Dava Kunci: } \\
\text { Fisik dan Fasilitas } \\
\text { Toko }\end{array}$ & & $\begin{array}{l}\text { Saluran: } \\
\text { 1.FisikToko } \\
\text { 2.Katalog, SMS/ } \\
\text { WA Blast/Email } \\
\text { 3. Pengembangan } \\
\text { Food Court } \\
\text { 4. Standarisasi Proses ITC }\end{array}$ & \\
\hline \multicolumn{2}{|c|}{$\begin{array}{l}\text { Struktur Biava: } \\
\text { 1.Biaya Tetap (gaji, sewa gedung, dll) } \\
\text { 2.Biaya Variabel (listrik, air, gas, non trade, dll) }\end{array}$} & \multicolumn{2}{|c|}{$\begin{array}{l}\text { Alur Pendapatan: } \\
\text { 1. Penjualan Barang Dagangan } \\
\text { 2.Penyewaan Tempat } \\
\text { 3. Konsinyasi/Bagi Hasil }\end{array}$} & \\
\hline
\end{tabular}

Gambar 5. Penyempurnaan model bisnis kanvas Supermarket XYZ

\section{Implikasi Manajerial}

Hasil analisis MBK Supermarket XYZ dengan prioritas strategi yang telah disusun tersebut dapat dijadikan dasar dalam perencanaan pengembangan bisnis ke depan. Masukan, saran dan rekomendasi yang diberikan kepada Supermarket XYZ dilakukan berdasarkan strategi prioritas yang ditentukan dan dipilih dari hasil analisis SWOT pada masing-masing elemen MBK yaitu saluran, hubungan pelanggan dan aktivitas kunci.

Prioritas strategi yang dihasilkan dapat dilaksanakan secara bersamaan maupun masingmasing, bergantung kepada lingkungan internal maupun eksternal, serta sumberdaya yang dimiliki oleh supermarket XYZ dalam mencapai tujuan perusahaannya.

1. Implikasi manajerial pada elemen saluran adalah pengembangan food court. Beberapa saran dan masukan untuk mendukung strategi ini adalah (a) penyusunan standar operasi dan prosedur (SOP); (b) bekerjasama dengan mitra usaha restoran dan makanan; dan (c) melakukan aktivitas promosi dan pemasaran. Kemudian, standarisasi proses dengan inspired the customers dapat dilakukan dengan: (a) penyusunan standar operasi dan prosedur (SOP);

(b) mengembangkan pelatihan karyawan.

2. Implikasi manajerial pada elemen hubungan pelanggan adalah strategi kerjasama pengembangan promosi dengan pihak ketiga yang dapat dilakukan dengan: (a) bekerjasama dengan bank untuk pengembangan promosi dengan kartu kredit; (b) melakukan aktivitas marketing, sebagai sarana promosi dan komunikasi kepada pelanggan. Selanjutnya, program After sales Service yang dapat dilakukan dengan (a) penyusunan standar operasi dan prosedur (SOP); (b) melakukan standarisasi pelayanan terhadap staf toko; (c) melakukan aktivitas marketing, sebagai sarana sosialisasi dan komunikasi kepada pelanggan.

3. Rekomendasi pada elemen aktivitas kunci adalah strategi dalam pelatihan karyawan yang dapat dilakukan dengan (a) membuat kurikulum pelatihan; (b) melakukan pelatihan dan evaluasi secara berkala kepada staf. Pengembangan produk dapat dilakukan dengan (a) melakukan analisis kebutuhan produk pelanggan yang belum terpenuhi; (b) kerja-sama dengan mitra usaha untuk pengembang-an produk yang unik, eksklusif dan diferensia-si; (c) memberikan pelatihan penanganan produk dan pengetahuan produk kepada staf toko.

\section{KESIMPULAN}

Identifikasi dan analisis strategi pada Supermarket XYZ dilakukan melalui penerapan sembilan elemen dalam model bisnis kanvas (MBK). Perbaikan strategi tersebut bertujuan untuk memperbaiki kondisi Supermarket XYZ sebagai langkah pengembangan strategi di masa depan dengan melakukan formulasi strategi pada tiga elemen yaitu: Saluran, Hubungan Pelanggan dan Aktivitas Kunci. Ketiga elemen tersebut dipilih karena memiliki pengaruh besar terhadap keenam elemen lainnya serta pengembangan strategi Supermarket XYZ. 
Elemen Saluran, Hubungan Pelanggan dan Aktivitas Kunci masing-masing dianalisis dan diperoleh strategi dengan menggunakan matriks SWOT. Proritas strategi dipilih dengan menggunakan metode kombinasi SWOT-AHP. Prioritas strategi yang dipilih pada elemen saluran, yaitu pengembangan food court dan standarisasi proses dengan inspired the customers.

Prioritas strategi yang dipilih dari elemen hubungan pelanggan merupakan program promosi khusus dengan pihak ketiga dan pegembangan program after sales service kepada pelanggan. Prioritas strategi yang dipilih dari elemen aktivitas kunci adalah pengembangan pelatihan kepada karyawan, serta pengembangan produk-produk yang unik, eksklusif dan diferensiasi di Supermarket XYZ.

\section{DAFTAR PUSTAKA}

David, F. 2009. Strategic Management, Concept and Case, edisi ke-12. New Jersey (US). Pearson Education

Osterwalder, A., Y. Pigneur. 2014. Business Model Generation. Jakarta (ID). PT. Elex Media Komputindo

Osuna, A. 2007. Combining SWOT and AHP, Technique for Strategic Planning. Journal Management of Business Management. 2(6):1225.

Rangkuti, F. 2013. Analisis SWOT Teknik Membedah Kasus Bisnis. Jakarta (ID): PT Gramedia Pustaka Utama.

Rahanta, T. 2012. Membangun Sinergi Pasar Tradisional dan Modern. Di dalam: Basri C. Rumah ekonomi Rumah budaya, Membaca Kebijakan Perdagangan Indonesia. Jakarta (ID). Gramedia Pustaka Utama. hlm 239261.

USDA. 2015. Foreign Agricultural Service. Indonesia Retail Report Update 